\title{
Aeromagnetic and Aeromagnetic-based Geologic Maps of the Coastal Belt, Franciscan Complex, Northern California
}

By V.E. Langenheim, R.C. Jachens, C.M. Wentworth, and R.J. McLaughlin

Pamphlet to accompany

Scientific Investigations Map 3188

Version 1.1, May 2017 
This page intentionally left blank 


\section{Contents}



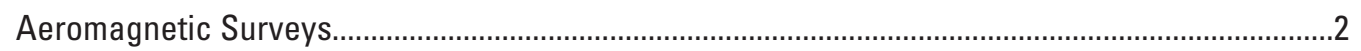

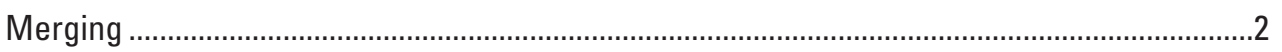

Aeromagnetic Map Processing and Anomaly Enhancement ……..................................................

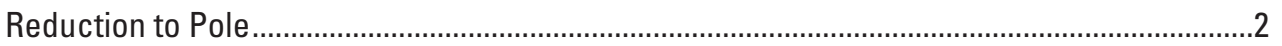

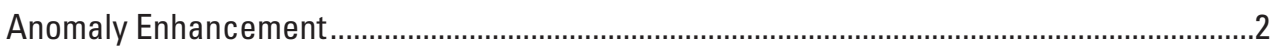

Locating Edges of Magnetic Bodies....................................................................................

Anomaly Sources and Magnetic Susceptibility Measurements .........................................................

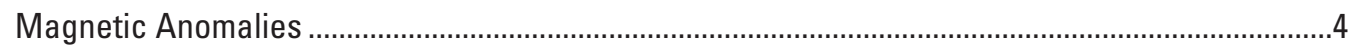

Approximate Dips Inferred from Residual Aeromagnetic Anomalies................................................

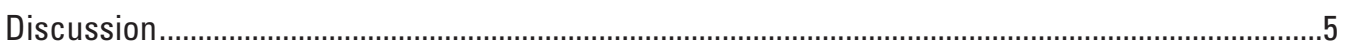

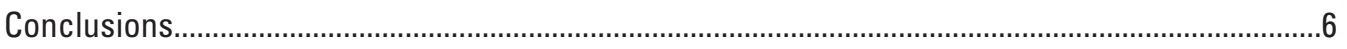

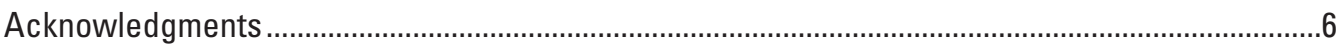

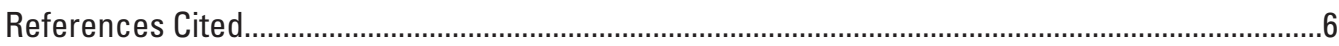

Figures

1. Index map of coastal California showing geology simplified from Jennings and others

(1977)

2. Geologic map of the study area ...................................................................................

3. Magnetic susceptibility measurements of various rock types in the Coastal belt.............11

4. Aeromagnetic, ground magnetic, and magnetic susceptibility data for the Fort Ross

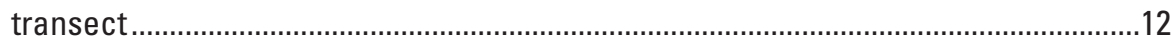

5. Predicted magnetic anomalies (reduced to pole) for vertical and dipping magnetic

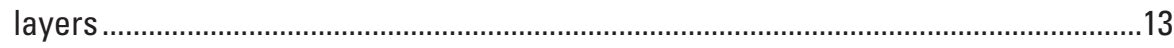

6. Aeromagnetic map of Laguna Point area, showing ground-magnetic traverse, groundmagnetic data, magnetization boundaries, and locations of magnetic susceptibility



7. Magnetic susceptibility measurements from the Laguna Point area.................................15

8. Model across the Laguna Point magnetic anomaly...........................................................16

9. Interpreted magnetic anomalies of the Coastal belt superposed on geology from

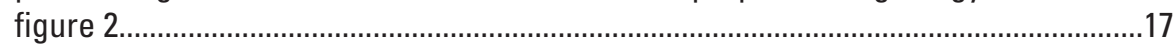

Tables



2. Interpreted strikes and dips from magnetic anomalies. ..............................................19

Sheets

1. Map A. Mosaic aeromagnetic map of the northern Coast Ranges, California superposed on shaded-relief topography. Map B. Merged shaded-relief aeromagnetic map of the northern Coast Ranges, California. Mendocino, Redding, and Yorkville surveys upward continued $150 \mathrm{~m}$ to match the average height above ground for the Ukiah survey.

2. Residual, reduced-to-pole aeromagnetic map of the northern Coast Ranges, California.

3. Residual, reduced-to-pole aeromagnetic map of the northern Coast Ranges, California, with interpreted dips from asymmetry of residual magnetic anomalies. 
This page intentionally left blank 


\section{Introduction}

The Coastal belt of the Franciscan Complex represents a Late Cretaceous to Miocene accretionary prism and overlying slope deposits. Its equivalents may extend from the offshore outer borderland of southern California (Vedder, 1987; McCulloch, 1987) to north of the Mendocino Triple Junction under the Eel River Basin (Bachman and others, 1984; fig. 1) and in the offshore of Cascadia (Aalto and others, 1995; McLaughlin and others, 2000; Stewart and Brandon, 2004). The Coastal belt is exposed on land in northern California, yet its structure and stratigraphy are incompletely known because of discontinuous exposure, structural disruption, and lithologically non-distinctive clastic rocks. The intent of this report is to make available, in map form, aeromagnetic data covering the Coastal belt that provide a new dataset to aid in mapping, understanding, and interpreting the incompletely understood geology and structure in northern California.

Coastal belt rocks crop out from Bodega Bay in the south to Cape Mendocino in the north, and as much as $50 \mathrm{~km}$ east of the coast (fig. 2). The eastern margin of the belt is marked in northern California by the Coastal Belt Thrust, which places largely older, higher grade rocks of the Central belt of the Franciscan Complex (Bailey and others, 1964; Blake and others, 1988) above the Coastal belt. The Coastal belt also underlies the offshore region north of Point Arena east of the offshore San Andreas Fault (fig. 1). Some areas of the Coastal belt are mapped in varying degrees of detail (Kleist, 1974; O’Day, 1974; Kramer, 1976; Blake and others, 2002; McLaughlin and others, 2000; Beutner and others, 1980; Orchard, 1979; Jayko and others, 1989), but the region between the Sonoma County line (dashed black line in fig. 2) and latitude $39^{\circ} 30^{\prime}$ is mapped only at a scale of 1:250,000 or smaller (Jennings and Strand, 1960; Wagner and Bortugno, 1982; Jennings and others, 1977, at a scale of 1:750,000). The region is sparsely populated, a circumstance that has provided little incentive for modern detailed mapping.

Following the convention of McLaughlin and others (2000), the Coastal belt can be divided into several terranes (fig. 2). The Coastal terrane is the largest and most lithologically diverse terrane of the belt. The terrane consists largely of pervasively sheared graywacke, shale, and minor conglomerate, with rare but characteristic exotic blocks of volcanic rock, pelagic limestone, chert and extremely rare blocks of blueschist. The Yager terrane is broadly coeval with the Coastal terrane but is less deformed and more lithologically homogeneous. The absence of exotic blocks and of Cretaceous fossils in the Yager terrane differentiates it from the Coastal terrane. The sandstones were deposited in a slope setting structurally above and likely interfingered with the accreted strata of the Coastal terrane (Bachman and others, 1984; McLaughlin and others, 1994). The Miocene King Range and False Cape terranes represent the youngest recognized accretion-related terranes of the Franciscan Complex (McLaughlin and others, 1982; Aalto and others, 1995; McLaughlin and others, 2000); their age and presence of diatoms differentiate them from the Coastal and Yager terranes.

Graywackes, which are by far the dominant rock type in the Coastal belt, are difficult to distinguish from one another in hand specimen or at outcrops. Underwood and Bachman (1986) were able to document five sandstone petrofacies within the Coastal and Yager terranes by using petrographic analyses. In addition, outcrops are discontinuous, much of the area is covered with vegetation, in places the regolith and soil exceed 10 $\mathrm{m}$ in thickness (Kramer, 1976) and land access can be difficult in many places. Most of the fresh rock outcrops are limited to sea cliffs, stream channels, roads, and quarries. Of this subset, Kramer's (1976) detailed work in the Fort Bragg-Willits area showed that road cuts and river channels often exhibit evidence of mass movement. Finally, the geology and structure of the Coastal belt are complicated due to its origin and assembly as a subduction zone accretionary complex, subsequently overprinted by deformation associated with the northward migration of the Mendocino triple junction. All of these factors, coupled with a dominantly graywacke and argillite composition, limit the ability to infer continuity between outcrops of the Coastal belt. Thus, interpretations based on widely scattered observations can be difficult.

Modern aeromagnetic surveys over northern California have been collected during the past few decades to aid in the understanding of the geology of the region and help evaluate the risks of natural hazards. These surveys were conducted from low-flying aircraft and measured local irregularities (anomalies) in the geomagnetic field that are caused by the presence of magnetic minerals, mostly magnetite, in the underlying rocks. Magnetic anomalies often can be related to rock type, and so the surveys provide a means to map remotely some aspects of the geology.

Some of the aeromagnetic surveys (for example, Santa Rosa/Napa Valley, Yorkville, sheet 1, map a, table 1) over the southern part of the Coastal belt have revealed puzzling magnetic anomalies that potentially imply a surprising degree of regularity, coherence, and spatial continuity of rock bodies within this terrane (Phelps and others, 2008a,b). Lowamplitude, curvilinear anomalies suggest near-surface or outcropping magnetic rock units 1-2 km wide and 10-40 km long. These magnetic anomalies are spatially pervasive, with anomalies generally 3-4 km apart. Subsequent surveys farther north (for example, Ukiah, table 1) show a continuation of this basic pattern over the Coastal belt, although the anomalies become somewhat less pervasive to the north and more widely separated - up to 5 or $6 \mathrm{~km}$ apart (sheet 1, map a). Some of the map anomaly patterns are suggestive of magnetic layers in plunging folds, as discussed subsequently.

With the completion of the Ukiah survey, it is appropriate to release these data in the form of a comprehensive aeromagnetic map (sheet 1, map b). In this report, we also include two derivative maps of low-amplitude anomalies, numerically enhanced to present the data more clearly for use in support of geologic mapping. As detailed in the following discussion, the first derivative map shows anomalies that arise from exposed or shallowly buried magnetic sources (sheet 2). The second derivative map includes the results of an automatic routine for defining near-surface "edges" of magnetic bodies and a basic interpretation of these anomalies in terms of magnetic layers, with associated interpreted strikes and dips (sheet 3 ). 


\section{Aeromagnetic Surveys}

Six surveys cover the outcrop area of the Coastal belt (table 1). These surveys were collected during the past three decades as integral parts of U.S. Geological Survey investigations of the following: (1) mineral resources in proposed wilderness areas; (2) active faulting; (3) the plate tectonic development of northern California; and (4) regional geologic mapping.

Data from all surveys were corrected for diurnal and other short-period magnetic fluctuations resulting from atmospheric and ionospheric sources, and corrected for the Earth's main magnetic field (the International Geomagnetic Reference Field [IGRF]; Langel, 1992) updated to the time period during which the data were collected. The resulting data were interpolated to a rectangular grid with nodes spaced $200 \mathrm{~m}$ apart according to an algorithm based on minimum curvature (Briggs, 1974). The resulting aeromagnetic survey maps are presented on sheet 1 .

\section{Merging}

Some minor manipulation and processing of the aeromagnetic data shown in sheet 1, map a were required to merge the individual surveys into a relatively seamless map of the Coastal belt (sheet 1, map b). Even though the survey data were all collected at nominally the same height above the ground surface, differences in topographic relief between areas and differences in the ruggedness of topography between areas caused safety concerns that resulted in some surveys being flown, on average, slightly higher or lower than adjacent surveys. These differences were compensated by numerically adjusting the flight height of some surveys to a slightly different observation surface, a procedure known as upward continuation (Grant and West, 1965). The Cape Mendocino, Santa Rosa/Napa Valley, Yorkville, and Redding surveys were upward-continued $150 \mathrm{~m}$ to be consistent with the average terrain clearance of the Ukiah survey. In addition, although the data were theoretically reduced to the same magnetic datum by corrections for diurnal variations and the IGRF, in practical terms there is slight arbitrariness in the resulting magnetic datum. Therefore, the magnetic datum levels of adjacent surveys were compared in areas of overlap, and the individual surveys were adjusted by adding a constant to all magnetic values within individual surveys. Finally, the individual adjusted surveys were merged into a single data set by smooth interpolation across a 1-km-wide buffer zone between surveys, resulting in the unified map shown on sheet 1 , map b.

\section{Aeromagnetic Map Processing and Anomaly Enhancement}

The long, curvilinear magnetic anomalies that characterize the Coastal belt are readily evident on sheet 1 , maps a and $b$, but some simple numerical filtering and manipulation can enhance these anomalies and present them in a way that should be easier to use for investigators who are not experts in potential-field geophysics. We have applied three straightforward procedures to the data in sheet 1 , map $b$, to produce the map shown on sheet 2 .

\section{Reduction-to-Pole Aeromagnetic Map}

Magnetic anomalies produced by rocks with magnetic minerals as a result of induction by Earth's main magnetic field tend to be asymmetric even when the bodies themselves have a symmetric geometry. Remanent magnetization probably does not contribute significantly to the magnetic anomalies, given the rock types within the Franciscan Complex. The asymmetry is caused by the non-vertical main magnetic field and thus is a function of magnetic latitude. In the Coastal belt region, for example, magnetic anomalies over symmetric, vertically dipping tabular bodies display magnetic lows on their north sides with the deepest magnetic lows just north of the north edges of the bodies and magnetic highs on their south sides with the strongest magnetic highs just north of the south edges of the bodies.

A numerical procedure called "reduction to the pole" (Baranov and Naudy, 1964) transforms observed anomalies into those that would have been measured at the magnetic pole where the main field is vertical. This transformation has the effect of centering the magnetic highs over the centers of the magnetic bodies, with flanking lows on all sides of the highs. For the Coastal belt region, the inclination and declination (within one degree) of the Earth's magnetic field is $62^{\circ}$ and $15^{\circ}$, respectively.

\section{Anomaly Enhancement}

Aeromagnetic maps in general, and the maps $a$ and $b$ on sheet 1 in particular, constitute a set of superposed anomalies of many different spatial wavelengths. The amplitude of magnetic anomalies attenuates with increased distance to the magnetic source and short-wavelength anomalies attenuate more severely with increased distance compared to longer wavelength anomalies. In general, the shortest wavelength anomalies are caused by magnetic bodies at or close to the surface, whereas longer wavelength anomalies typically are caused by deeper magnetic source bodies. Thus, the shortest wavelength anomalies on sheet 1 , map $b$ are most likely produced by units that crop out or are only shallowly buried - those units that most likely would be found in outcrop or would reflect structures found in outcrop, and would be depicted on a traditional geologic map. These shortest wavelength anomalies are the anomalies of most direct interest to geologic mapping.

The more severe attenuation with distance of shortwavelength magnetic anomalies (relative to longer wavelength anomalies) provides the basis for a simple filter to enhance the anomalies from near-surface sources. If $\mathrm{M}_{\text {pole }}$ is the magnetic anomaly field shown in sheet 1 , map b, reduced to the pole, 
then a magnetic anomaly field with short-wavelength anomalies enhanced with respect to longer-wavelength anomalies $\left[\mathrm{M}_{\text {pole }}\right]_{\text {residual }}$ is given by

$$
\left[\mathrm{M}_{\text {pole }}\right]_{\text {residual }}=\mathrm{M}_{\text {pole }}-\left[\mathrm{M}_{\text {pole }}\right](\text { up } 200 \mathrm{~m})
$$

where $\left[\mathrm{M}_{\text {pole }}\right]$ up $200 \mathrm{~m}$ is the magnetic anomaly field of sheet 1 , map b, reduced to the pole and upward continued to a surface $200 \mathrm{~m}$ above the original measurement surface, which produced the most continuous, short-wavelength anomalies. The procedure is essentially a discrete vertical derivative. This residual field is the magnetic anomaly field shown on sheets 2 and 3.

\section{Locating Edges of Magnetic Bodies}

Cordell and Grauch (1985) devised a scheme for locating the near-surface sharp edges of magnetic bodies based on the anomalies magnetic bodies produce and a mathematical transformation called the pseudogravity transform (Baranov, 1957). Blakely and Simpson (1986) automated this scheme for application to digital representations of magnetic anomaly fields, and the result is a mapped distribution of closely spaced points that define the edges of magnetic bodies.

The small, white-filled circles shown on sheet 3 represent the inferred surface contacts of outcropping magnetic bodies or the sharp, near-surface edges of shallowly buried magnetic bodies that produce the short-wavelength magnetic anomalies shown on sheet 1 , map $b$; and sheet 2 . These points were automatically generated by applying the method of Blakely and Simpson (1986) to $\left[\mathrm{M}_{\text {pole }}\right]_{\text {residual }}$. This method assumes that the magnetic bodies have vertical sides. For non-vertical sides, calculated points will shift in the direction of dip. For sides with moderate to steep dip ( $45^{\circ}$ to vertical), however, the horizontal displacement of a gradient maximum from the top edge of an offset horizontal layer is always less than, or equal to, the depth to the top of the source (Grauch and Cordell, 1987). Because of the altitude that the data were collected, the resulting aeromagnetic anomaly may be wider than the magnetic source, even if the magnetic source is exposed at the surface.

The various filters used to produce the magnetic anomaly field shown on sheets 2 and 3 (reduction to the pole, upward continuation, anomaly enhancement, and pseudogravity transform) are all linear filters so that the results are independent of the order in which the filters are applied (Blakely, 1995).

\section{Anomaly Sources and Magnetic Susceptibility Measurements}

Preliminary field investigations, comparisons between the magnetic anomaly map and available geologic maps, and magnetic susceptibility measurements suggest at least four different general sources for the long, narrow curvilinear magnetic anomalies that characterize the Coastal and Central belts of the Franciscan Complex.

1. Serpentinite and related ultramafic rocks, shown in many places to be dismembered parts of the Coast Range ophiolite. These rocks are complexly imbricated in the Central belt, notably along the Coastal Belt Thrust (McLaughlin and others, 2000; McLaughlin and others, 1988). At the surface Coast Range ophiolite, remnants appear as thin, dipping, discontinuous, tabular bodies entrained in the country rock during the accretion process. These remnants were likely later modified by strike-slip faulting. They typically define suture zones, such as the Coastal Belt Thrust (McLaughlin and others, 1988; 2000). Serpentinites contain abundant magnetite and typically are highly magnetic.

2. Franciscan Complex metavolcanic rocks. These have been shown to represent accreted fragments of oceanic basalt from subducted oceanic basement, including seamounts or oceanic plateaus (McLaughlin and others, 1994; Sliter and others, 1986). Franciscan Complex metavolcanic rocks can be magnetic unless they have undergone extensive weathering, alteration, and metamorphism.

3. Lenses of Coastal belt conglomerates whose cobbles retain enough magnetite that the bulk magnetic properties of the units are higher than those of the surrounding finer grained clastic rocks. Where dated, these conglomerates are the same age as and clearly are interbedded in the dominant graywackes. They are interpreted to represent submarine canyon or channel fills (McLaughlin and others, 1994; Underwood and Bachman, 1986).

4. Lithic, volcanic-rich graywackes. These rocks most likely are a subset of the lithic Coastal belt petrofacies identified by Underwood and Bachman (1986) from samples near and north of Fort Bragg. Magnetically, these rocks appear to be thin, dipping, tabular bodies, commonly folded and fault-bounded.

Initial field investigations in the area south of Ukiah (Phelps and others, 2008a,b) found that the sources of many long, narrow, curvilinear magnetic anomalies over the Coastal belt are associated at the surface with graywackes rich in andesitic detritus. Magnetic susceptibility measurements of the graywacke (fig. 3; magenta and green stars on sheet 2) indicate many graywackes are weakly magnetic, with values less than $1 \times 10^{-3}$ SI units. Significantly, however, about a quarter of graywackes measured have susceptibilities large enough to produce magnetic anomalies measured at the height of the aeromagnetic surveys, with values greater than $2 \times 10^{-3}$ SI units and reaching values as high as $28 \times 10^{-3}$ SI units.

Field investigations also indicate that basaltic metavolcanic rocks are sources of many of the anomalies, particularly in the Fort Bragg-Willits area, where mapping (Kramer, 1976) indicates thin layers of metavolcanic rocks. Farther north, sparse outcrops of metavolcanic rocks are associated with magnetic anomalies in the Usal-Dugans and Julius' opening area (McLaughlin and others, 1994; O’Day, 1974; anomaly 5c, table 2), Parkhurst Ridge (PR on fig. 2), and Whitethorn areas 
(anomaly 5b, table 2; McLaughlin and others, 2000; Jayko and others, 1989). Magnetic susceptibility measurements indicate that the metavolcanic rocks in the Coastal belt can be very magnetic (fig. 3). Lower values measured on the metavolcanic rocks are due to extensive weathering or alteration, or intermixing of limestone and argillite with the volcanic rocks.

Mapped Tertiary conglomerate appears to coincide with several weakly positive magnetic anomalies north of Garberville; however, these conglomerates are a relatively minor constituent in the Coastal belt, and the conglomerates vary widely in their clast contents. A few measurements of conglomerate indicate generally low magnetic susceptibilities (fig. 3), but one Yager terrane conglomerate and one Yager terrane sandstone have magnetic susceptibilities that could account for the weak anomalies north of Garberville (sheet 2).

To illustrate the effectiveness of these magnetic data to map features on the ground, we used the aeromagnetic map to locate a previously undiscovered outcrop of basalt along the San Andreas Fault near Fort Ross. The aeromagnetic map shows a long, linear anomaly along and nearly parallel to the San Andreas Fault (fig. 4). We then performed a ground magnetic survey and acquired susceptibility measurements across the feature. The ground magnetic survey reveals an approximately 300-m-wide anomaly with an amplitude of $500 \mathrm{nT}$ (see fig. 4). The ground anomaly is much narrower and higher amplitude than that measured from the airplane ( $\sim 1 \mathrm{~km}$ wide, $20 \mathrm{nT}$ amplitude), an expected result due to the aeromagnetic survey height. Although outcrop quality was poor, we did locate a small outcrop of basalt that was highly magnetic $(\mathrm{K}=38-50$ $\mathrm{x} 10^{-3} \mathrm{SI}$ units) within the positive ground magnetic anomaly that had not been previously mapped. The absence of a prominent ground magnetic anomaly coincident with the magnetic graywacke along the Fort Ross road suggests that the magnetic graywackes may not be voluminous enough to produce the aeromagnetic anomaly in that area.

\section{Magnetic Anomalies}

The magnetic maps reveal regions that share anomaly characteristics. Although slightly magnetic terrain can produce measureable aeromagnetic anomalies, the anomaly patterns do not appear to coincide with topographic features (sheet 1, map a). The magnetic patterns can be related to terranes in the Coastal belt. The King Range terrane is marked by a smooth magnetic field with generally lower values; Griscom (1980) attributed this pattern to a substantial thickness of nonmagnetic sandstones. In general, the Yager terrane is characterized by a smooth magnetic field, except for the region northwest of Garberville that locally includes magnetic conglomerate and associated sandstone, where residual anomalies exceed $2 \mathrm{nT}$ in amplitude, and along the eastern margin of the terrane. The relatively smooth magnetic field is likely due to the absence of metavolcanic rocks. Along the eastern margin of the Yager terrane, prominent magnetic anomalies mark the location of the Coastal Belt Thrust where it is well mapped outside of the
Ukiah $1^{\circ}$ by $2^{\circ}$ quadrangle. These anomalies are caused by interleaving of Coast Ranges ophiolite within and along the Coastal Belt Thrust. This correlation suggests that it may be possible to more accurately map the location of the thrust fault within the Ukiah $1^{\circ}$ by $2^{\circ}$ quadrangle.

The Coastal terrane is marked by numerous, west-northwest- to north-northwest-trending, linear to arcuate positive anomalies that locally extend to the west offshore. These anomalies do not extend across the San Andreas Fault Zone, which is characterized by a set of north-trending anomalies. The eastern margin of the terrane is marked by a subtle transition to the generally smoother magnetic field of the Yager terrane, generally north of Laytonville.

Changes in regional magnetic patterns within the Coastal terrane are located at about lat $39^{\circ} 37.5^{\prime} \mathrm{N}$. and at about lat $39^{\circ} \mathrm{N}$. The anomalies over the southern part of the terrane, south of about lat $39^{\circ} \mathrm{N}$., appear to coincide with closely spaced structural repetition of Coastal and Central belt rocks and by the complex folding and compression of the Coastal Belt Thrust by younger west-northwest-trending reverse faults. The anomaly pattern is marked by closely spaced $(3-4 \mathrm{~km})$ anomalies and reflects three known anomaly sources: graywacke, metabasalt, and serpentinite. Serpentinite is associated with rocks derived from the Coast Range ophiolite entrained within the Coastal Belt Thrust Zone and shear zones within the Central belt. The region between latitudes $39^{\circ} 37.5^{\prime} \mathrm{N}$. and $39^{\circ} \mathrm{N}$. is characterized by a prevalent $\mathrm{N} 40-60^{\circ} \mathrm{W}$ anomaly trend, with a wider spacing between anomalies than those to the south. Both basalt and graywacke are known magnetic sources in this part of the Coastal terrane. North of lat $39^{\circ} 37.5^{\prime} \mathrm{N}$. to the latitude of the town of Petrolia, magnetic anomalies are characterized by more northerly trends of N. 10-30 $0^{\circ}$ W. Many of these anomalies coincide with small, discontinuous and sheared exposures of basalt. Near the northern extent of exposed Coastal belt rocks, anomaly trends swing to the west and extend offshore along the south side of the Eel River Basin; see also figures 2 and 9.

\section{Approximate Dips Inferred from Residual Aeromagnetic Anomalies}

The magnetic anomalies shown in sheet 2 provide an opportunity to estimate the dip of magnetic graywacke or metavolcanic layers within the Coastal belt. On sheet 2, a vertical tabular body should produce a symmetric magnetic anomaly high centered over the body, with adjacent lows on both side of the high that are the same shape and amplitude. If the tabular body is not vertical but instead dips, then the low on the side toward the dip direction will be diminished relative to the low on the opposite side (fig. 5). The discrepancy becomes more pronounced as the dip shallows. Thus, anomaly asymmetry on a "reduced to pole" magnetic anomaly map can yield information about both dip direction and an approximate dip angle.

Interpretations of dip direction and dip angle from maps such as sheet 3 must be made with caution because other factors 
can influence magnetic anomaly asymmetry. Primary among possible complications are interference between overlapping anomalies and non-tabular source geometry, but other factors such as non-uniform distribution of magnetic minerals, possible remanent magnetization not oriented along the present Earth's main magnetic field direction, and others not yet discovered could lead to erroneous interpretations. This method should be applicable to the Franciscan Complex because remanent magnetization in the Franciscan Complex rocks is weak. Despite these potential issues, many of the anomalies show surprising lateral continuity and consistency in dip direction along strike, suggesting that some of these complicating factors may not be major factors.

We have qualitatively examined the long curvilinear magnetic anomalies over the Franciscan Complex Coastal belt and have interpreted source body dip direction, approximate dip angle, and measurement confidence for nearly 50 individual anomalies (sheet 3; table 2). These data are presented on sheet 3 by symbols described in the map legend. This exercise was conducted as a blind test without reference to the generally sparse dip information on available geologic maps. The dips were estimated by determining the amplitude asymmetry from the grid and were not the result of forward modeling of each anomaly.

Subsequent to our interpretation, we performed a groundmagnetic survey in the Laguna Point area (fig. 2), where one of the curvilinear magnetic anomalies crosses the coastline (anomaly $25 \mathrm{~b}$, sheet 3 ). This area was a good place to test the airborne results because graywacke and metavolcanic rocks along the coast are well exposed and are easily accessible. Groundmagnetic measurements indicate a magnetic high that is about $200 \mathrm{~m}$ wide, much narrower than the anomaly measured at the height of the airborne survey ( 1000 m; fig. 6) as expected. Magnetic susceptibility measurements indicate that the metavolcanic rocks are the source of the anomaly. The graywackes are weakly magnetic; the contacts between the blocks of metavolcanic rocks and the graywackes are highly sheared, locally incorporating thin streaks of argillite and pink, pelagic limestone and leading to intermediate magnetic values for both rock types (fig. 7). We projected the width of the outcrop of exposed basalt from the coast to the profile to help constrain the forward model of the ground-magnetic data. With this constraint, the model (fig. 8) indicates a steep south dip for the magnetic volcanic rocks, consistent with structural attitudes measured on the graywacke (David Andersen and Jeana Lopez, written commun., 2010; fig. 6) and consistent with our interpreted dip from the airborne data ( $25 \mathrm{~b}$ on sheet 3 and table 2 ). The measured strikes of the graywacke are also broadly consistent with the strike of the aeromagnetic anomaly. This test indicates that the method of using the asymmetry of the reduced-to-pole aeromagnetic anomaly can be successfully applied and that the magnetization boundaries derived from aeromagnetic anomalies may be not only considerably wider than the magnetic rocks exposed at the surface, but also shifted.

\section{Discussion}

The magnetic anomalies point to coherent structures within the Coastal belt, despite its characterization of the dominant structure within the Coastal belt as "broken formation". For the Fort Bragg area, three deformational episodes have been discussed. Although several workers (for example, Kramer, 1976; O’Day, 1974; Kleist, 1974) have described a first generation of deformation as consisting of submarine landsliding and softsediment deformation, these features have chaotic orientations, and thus do not appear responsible for the coherent magnetic anomalies of the Coastal belt.

The second phase of deformation described by Kramer (1976) and others produced the most noticeable and severe deformation, resulting in northwest-trending folds and faults. Many of the magnetic bodies trend northwest and dip to the northeast (sheet 3; fig. 9), consistent with this second phase of deformation, which Kramer (1976) attributed to structural interleaving of tectonic blocks and slabs of ocean floor within an accretionary complex during subduction of the Farallon Plate beneath the North American Plate. Kramer's third generation of deformation produced broad, east-west trending folds that also are not evident in the magnetic data.

Other studies of the Yager and Coastal terranes north of the Fort Bragg area point to an early generation of large-scale recumbent folding overprinted by later upright isoclinal folds in the Coastal belt (Beutner and Hanson, 1975; Beutner and others, 1980; McLaughlin and others, 1994). Superposed on these folds is pervasive brittle deformation (boudinage, shearing, and crush zones) that breaks up and transposes fold limbs. The magnetic signature of the Coastal belt, however, suggests that the brittle deformation that is so apparent in surface outcrops apparently was not extensive enough to obliterate the record of folding in the Coastal belt accretionary complex.

The eastern margin of the Coastal belt is marked by anomalies that trend more northerly than those in the western margin of the belt and whose source bodies are interpreted to dip predominantly to the northeast. These anomalies likely are caused by serpentinites within the Coastal Belt Thrust, which is poorly mapped in the southern half of the Ukiah $1^{\circ} \times 2^{\circ}$ quadrangle, but which coincides with magnetic anomalies north of lat 39³0' N. (Jayko and others, 1989; McLaughlin and others, 2000) and has been mapped using aeromagnetic anomalies north of the study area (Clarke, 1992). The northeast dips of these sources are consistent with the northeast dip for the Coastal Belt Thrust.

The magnetic anomalies in the Coastal belt are caused by multiple sources. Along its southern margin, anomalies associated with the Coast Ranges ophiolite can be traced into the Coastal belt and are largely due to the northwestward translation of Coast Range ophiolite in the Coastal Belt Thrust along steeply dipping reverse faults that disrupt the Coastal Belt Thrust. Previously, serpentinite slices imbricated with rocks of the Franciscan Complex were considered to be Franciscan Complex basement; however, recent work argues that all serpentinites within the Franciscan Complex represent basement of the Coast Ranges ophiolite that has been tectonically interleaved 
with the Franciscan Complex during accretion and subsequent faulting (M.C. Blake, Jr., written commun., 2011). Metavolcanic or basalt blocks clearly are responsible for magnetic anomalies throughout the Coastal terrane. At least two to three distinct "layers" of graywacke produce magnetic anomalies suggestive of plunging folds. For example, a horseshoe-shaped anomaly (26a on sheet 3 , table 2) may represent a plunging antiform, with anomaly 27 representing another layer that is part of this structure.

The magnetic data allow for differentiating the generally monotonous graywacke within the Coastal terrane into two groups that reflect potentially different source regions. Preliminary work (Phelps and others, 2008a,b) shows that the magnetic properties of graywackes, primarily from the southern half of the Coastal terrane, are due to andesitic debris. Further work is needed to determine if these observations apply to the entire Coastal belt and to pinpoint the source(s) of the andesitic detritus. The aeromagnetic data also may help delineate lithofacies within the Yager terrane that were described by Underwood and Bachman (1986). Their petrographic data suggest that the northern part of the Yager terrane contains a higher percentage of feldspar and volcanic lithic clasts than does the southern part of the terrane. To first order, the magnetic data support such a distinction in that the southern part of the Yager terrane is characterized by a smoother magnetic field than that of the northern Yager terrane. The boundary between the Yager and Coastal terranes as mapped by Underwood and Bachman (1986) is not in the same place as depicted by Jayko and others (1989) and suggests that the location of the terrane boundary should be reexamined in the area of mismatch and particularly to the south of the Covelo quadrangle mapped by Jayko and others (1989). A smoother magnetic field may indicate the presence of weakly magnetic Yager terrane; the transition to the linear belt of the anomalies could mark the Yager-Coastal terrane boundary.

\section{Conclusions}

Newly merged aeromagnetic data over the Coastal belt of the Franciscan Complex reveal long, linear anomalies that indicate remarkably coherent structure within a terrane where mapping at the surface indicates complex deformation and that has been described as "broken formation" and, even locally as "mélange". The anomalies in the Coastal belt are primarily sourced by volcanic-rich graywackes and exotic blocks of basalt. Some anomalies along the contact of the Coastal belt with the Central belt are likely caused by local interleaving of components of the Coast Ranges ophiolite. These data can be used to map additional exotic blocks within the Coastal belt and to distinguish lithologically indistinct graywackes within the Coastal terrane. Using anomaly asymmetry allows projection of these "layers" into the subsurface. This analysis indicates predominant northeast dips consistent with tectonic interleaving of blocks within a subduction zone.

\section{Acknowledgments}

We thank Geoff Phelps and Jeana Lopez for providing additional magnetic susceptibility measurements from the Coastal belt. We also are grateful to Mike Underwood who provided samples from his thesis for physical property measurements. Jeana Lopez and Dave Andersen provided valuable structural attitudes from the Laguna Point area. We appreciate comments from Richard Blakely and Ray Wells that improved the manuscript and maps.

\section{References Cited}

Aalto, K.R., McLaughlin, R.J., Carver, G.A., Barron, J.A., Sliter, W.V., and McDougall, K., 1995, Uplifted Neogene margin, southernmost Cascadia-Mendocino triple junction region, California: Tectonics, v. 14, p. 1104-1116.

Bachman, S.B., Underwood, M.B., and Menack, J.S., 1984, Cenozoic evolution of coastal Northern California, in Crouch, J.K., and Bachman, S.B., eds., Tectonics and sedimentation along the California Margin: Pacific Section Society of Economic Paleontologists and Mineralogists, v. 38, p. 55-66.

Bailey, E.H., Irwin, W.P., and Jones, D.L., 1964, Franciscan and related rocks, and their significance in the geology of western California: California Division of Mines and Geology Bulletin, v. 183, 177 p.

Baranov, V.I., 1957, A new method for interpretation of aeromagnetic maps-Pseudo-gravimetric anomalies: Geophysics, v. 22, p. 359-383.

Baranov, V., and Naudy, H., 1964, Numerical calculation of the formula of reduction to the magnetic pole: Geophysics, v. 29, p. 67-79.

Beutner, E.C., and Hanson, E., 1975, Structural evidence of plate interactions from continental rocks, Cape Mendocino to Shelter Cove, California: Geological Society of America Abstracts with Program, v. 7, no. 7, p. 997.

Beutner, E.C., McLaughlin, R.J., Ohlin, H.N., and Sorg, D.H., 1980, Geologic map of the King Range and Chemise Mountain Instant Study Areas, northern California: U.S. Geological Survey, Miscellaneous Field Studies Map MF-1196-A, scale 1:62,500.

Blake, M.C., Jr., Graymer, R.W., and Stamski, R.E., 2002, Geologic map and map database of western Sonoma, northernmost Marin, and southernmost Mendocino Counties, California: U.S. Geological Survey Miscellaneous Field Studies Map MF-2402, scale 1:100,000, 45 p.

Blake, M.C., Jr., Jayko, A.S., McLaughlin, R.J., and Underwood, M.B., 1988, Metamorphic and tectonic evolution of the Franciscan Complex, northern California, in Ernst, W.G., ed., Metamorphism and crustal evolution of the western United States: New Jersey, Prentice Hall, Englewood Cliffs, p. 1036-1059.

Blakely, R.J., 1995, Potential theory in gravity and magnetic applications: Cambridge University Press, 441 p. 
Blakely, R.J., and Simpson, R.W., 1986, Approximating edges of source bodies from magnetic or gravity anomalies: Geophysics, v. 51, p. 1494-1498.

Briggs, I.C., 1974, Machine contouring using minimum curvature: Geophysics, v. 39, p. 39-48.

Clarke, S.J., Jr., 1992, Geology of the Eel River Basin and adjacent region-Implications for late Cenozoic tectonics of the Cascadia subduction zone and Mendocino triple junction: American Association of Petroleum Geologists Bulletin, v. 76, p. 199-224.

Cordell, Lindrith, and Grauch, V.J.S., 1985, Mapping basement magnetization zones from aeromagnetic data in the San Juan Basin, New Mexico, in Hinze, W.J., ed., The utility of regional gravity and magnetic anomaly maps: Tulsa, Okla., Society of Exploration Geophysicists, p. 181-192.

Griscom, Andrew, 1980, Aeromagnetic map and interpretation, King Range and Chemise Mountain, California: U.S. Geological Survey Miscellaneous Field Studies Map MF-1196-B, 2 sheets, scale 1:62,500.

Grant, F.S., and West, G.F., 1965, Interpretation theory in applied geophysics: New York, N.Y., McGraw-Hill, 584 p.

Grauch, V.J.S., and Cordell, Lindrith, 1987, Limitations of determining density or magnetic boundaries from the horizontal gradient of gravity or pseudogravity data: Geophysics, v. 52, no. 1, p. 118-121.

Jayko, A.S., Blake, M.C., McLaughlin, R.J., Ohlin, H.N., Ellen, S.D., and Kelsey, H.M., 1989, Reconnaissance geologic map of the Covelo 30- x 60-minute quadrangle, northern California: U.S. Geological Survey Miscellaneous Field Studies Map MF-2001, scale 1:100000.

Jennings, C.W., and Bryant, W.A., comps., 2010, Fault activity map of California: California Geological Survey Geologic Data Map no. 6, map scale 1:750,000.

Jennings, C.W., and Strand, R.G., 1960, Geologic map of California-Ukiah sheet: California Division of Mines and Geology, scale 1:250,000.

Jennings, C.W., Strand, R.G., and Rogers, T.H., comps., 1977, Geologic map of California: California Division of Mines and Geology, scale 1:750,000.

Kleist, J.R., 1974, Geology of the Coastal Belt, Franciscan Complex, near Ft. Bragg, California: Austin, University of Texas, $\mathrm{PhD}$ thesis, 133 p., 2 plates.

Kramer, J.C., 1976, Geology and tectonic implications of the Coastal Belt Franciscan Fort-Bragg-Willits area, northern Coast Ranges, California: Los Angeles, University of California, $\mathrm{PhD}$ thesis, 128 p., 4 plates.

Langel, R.A., 1992, International geomagnetic reference field - the sixth generation: Journal of Geomagnetism and Geoelectricity, v. 44, p. 679-707.

McCulloch, D.S., 1987, Regional geology and hydrocarbon potential of offshore central California, in Scholl, D.W., Grantz, Arthur, and Vedder, J.G., eds., Geology and resource potential of the continental margin of western North America and adjacent ocean basins-Beaufort Sea to Baja California (Earth Science Series, v. 6): Houston, Tex., Circum-Pacific Council for Energy and Mineral Resources, v. 6 , p. $353-401$.
McLaughlin, R.J., Blake, M.C., Jr., Griscom, Andrew, Blome, C.D., and Murchey, B.L., 1988, Tectonics of formation, translation, and dispersal of the Coast Ranges ophiolite of California: Tectonics, v. 7, p. 1033-1056.

McLaughlin, R.J., Ellen, S.D., Blake, M.C., Jayko, A.S., Irwin, W.P., Aalto, K.R., Carver, G.A., Clarke, S.H., Barnes, J.B., Cecil, J.D., and Cyr, K.A., 2000, Geology of the Cape Mendocino, Eureka, Garberville, and southwestern part of the Hayfork 30 X 60 minute quadrangles and adjacent offshore area, northern California, with digital database: U.S. Geological Survey Miscellaneous Field Studies Map MF-2336, scale 1:100,000.

McLaughlin, R.J., Kling, S.A., Poore, R.Z., McDougall, K., and Beutner, E.C., 1982, Post-middle Miocene accretion of Franciscan rocks, northwestern California: Geological Society of America Bulletin, v. 93, p. 595-605.

McLaughlin, R.J., Sliter, W.V., Frederiksen, N.O., Harbert, W.P., and McCulloch, D.S., 1994, Plate motions recorded in tectonostratigraphic terranes of the Franciscan Complex and evolution of the Mendocino Triple Junction, northwestern California: U.S. Geological Survey Bulletin 1997, 60 p.

O'Day, M.S., 1974, The structure and petrology of the Mesozoic and Cenozoic rocks of the Franciscan Complex, Leggett-Piercey area, northern California coast: University of California, Davis, $\mathrm{PhD}$ thesis, 152 p., 3 plates.

Orchard, David Merle, 1979, Geology of the Robinson CreekUkiah area, northern Coast Ranges, California: Austin, University of Texas, Master's thesis, $88 \mathrm{p}$.

Phelps, G.A., McLaughlin, R.J., Jachens, R.C., and Wentworth, C.M., 2008a, Aeromagnetic signatures reveal stratigraphic and structural relations in the Franciscan Complex east of the San Andreas fault, northern California: Geological Society of America Abstracts with Programs, v. 40, no. 1, p. 53.

Phelps, G.A., McLaughlin, R.J., Jachens, R.C., and Wentworth, C.M., 2008b, Using high resolution aeromagnetic data to map pervasive folding in the lithologically indistinct Franciscan Coastal Belt: Eos, v. 89, no. 53, Fall Meeting Suppl., Abstract GP43B-0815.

Sliter, W.V., McLaughlin, R.J., Keller, Gerta, and Evitt, W.R., 1986, Paleogene accretion of Upper Cretaceous oceanic limestone in northern California: Geology, v. 14, no. 4, p. 350-353.

Stewart, R.J., and Brandon, M.T., 2004, Detrital-zircon fissiontrack ages for the "Hoh Formation"- Implications for late Cenozoic evolution of the Cascadia subduction wedge: Geological Society of America Bulletin, v. 116, p. 60-75.

Underwood, M.B., and Bachman, S.B., 1986, Sandstone petrofacies of the Yager complex and the Franciscan Coastal belt, Paleogene of northern California: Geological Society of America Bulletin, v. 97, p. 809-817.

U.S. Geological Survey, 1985, Aeromagnetic map of the Redding 1 degree by 2 degree quadrangle, California: U.S. Geological Survey Open-File Report 85-757, scale $1: 250,000$.

U.S. Geological Survey, 1994, Aeromagnetic map of Cape Mendocino and vicinity, California: U.S. Geological Survey Open-File Report 94-444, scale 1:250,000. 
U.S. Geological Survey, 1996, Aeromagnetic map of the Clear Lake region on parts of the Santa Rosa and Ukiah 1 degree by 2 degree quadrangle, California: U.S. Geological Survey Open-File Report 96-691, scale 1:250,000.

U.S. Geological Survey, 1997, Aeromagnetic map of Santa Rosa and vicinity on parts of Santa Rosa and San Francisco 1 degree by 2 degree quadrangles, California: U.S. Geological Survey Open-File Report 97-468, scale 1:250,000.

U.S. Geological Survey, 2005, Seven aeromagnetic surveys in California and Nevada: A web site for distribution of data: U.S. Geological Survey Open-File Report 2005-1328, [available at http://pubs.usgs.gov/of/2005/1328/ca-nev. html, last accessed February 2, 2011].
Vedder, J.G., 1987, Regional geology and petroleum potential of the southern California borderland, in Scholl, D.W., Grantz, Arthur, and Vedder, J.G., eds., Geology and resource potential of the continental margin of Western North America and adjacent ocean basins-Beaufort Sea to Baja California (Earth Science Series, v. 6): Houston, Tex., Circum-Pacific Council for Energy and Mineral Resources, v. 6, p. 403-447.

Wagner, D.L., and Bortugno, E.J., 1982, Geologic map of the Santa Rosa quadrangle, California, 1:250,000: California Division of Mines and Geology, Regional Geologic Map 2A, scale 1:250,000. 


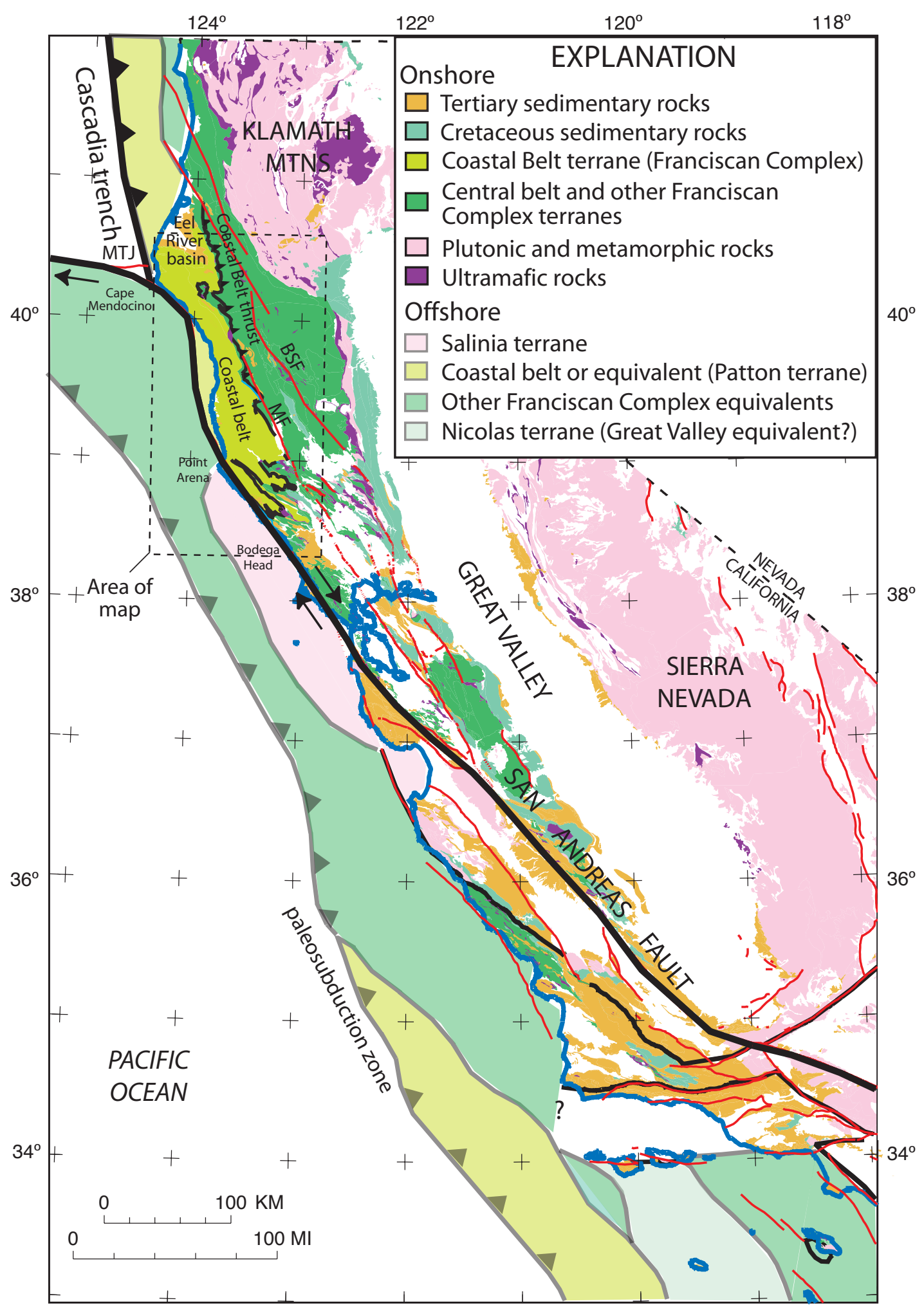

Figure 1. Index map of coastal California, showing geology simplified from Jennings and others (1977). Heavy black lines are plate boundaries. Black and gray lines are terrane boundaries generalized from McCulloch (1987), Vedder (1987), Clarke (1992), and Jennings and others (1977). Red lines are faults generalized from Jennings and Bryant (2010). BSF, Bartlett Springs Fault; MF, Maacama Fault; MTJ, Mendocino Triple Junction. 


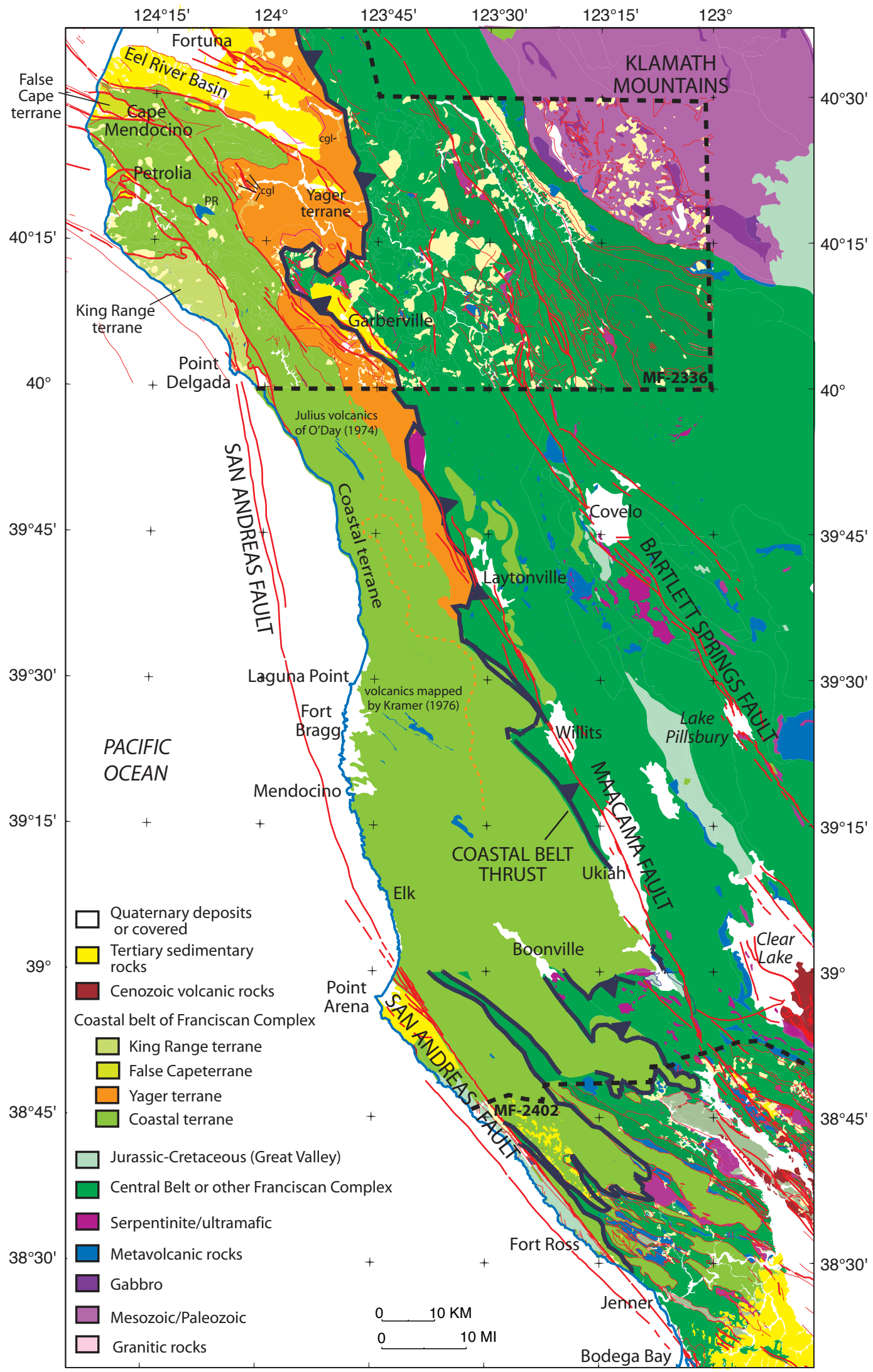

Figure 2. Geologic map of the study area. Dotted black lines show margins of more detailed, digital geologic maps (McLaughlin and others, 2000, [MF 2336]; Blake and others, 2002, [MF 2402]) that were simplified for this figure. Dotted orange line shows western contact of the Yager complex from Underwood and Bachman (1986), which differs significantly from the extent of the Yager terrane from Jayko and others (1989). Abbreviations: PR, Parkhurst Ridge; cgl, conglomerate. 


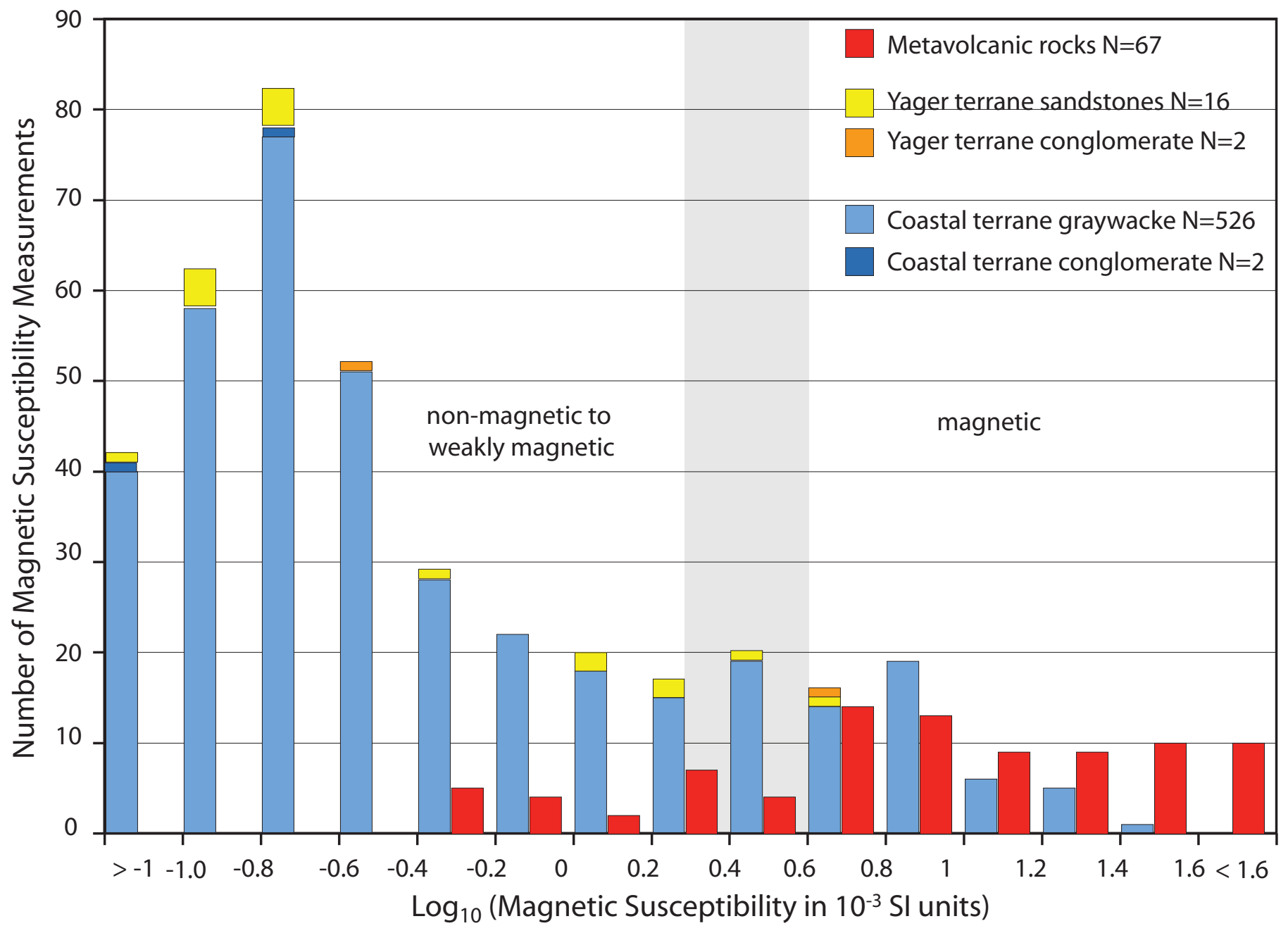

Figure 3. Magnetic susceptibility measurements of various rock types in the Coastal belt. N, number of measurements. 


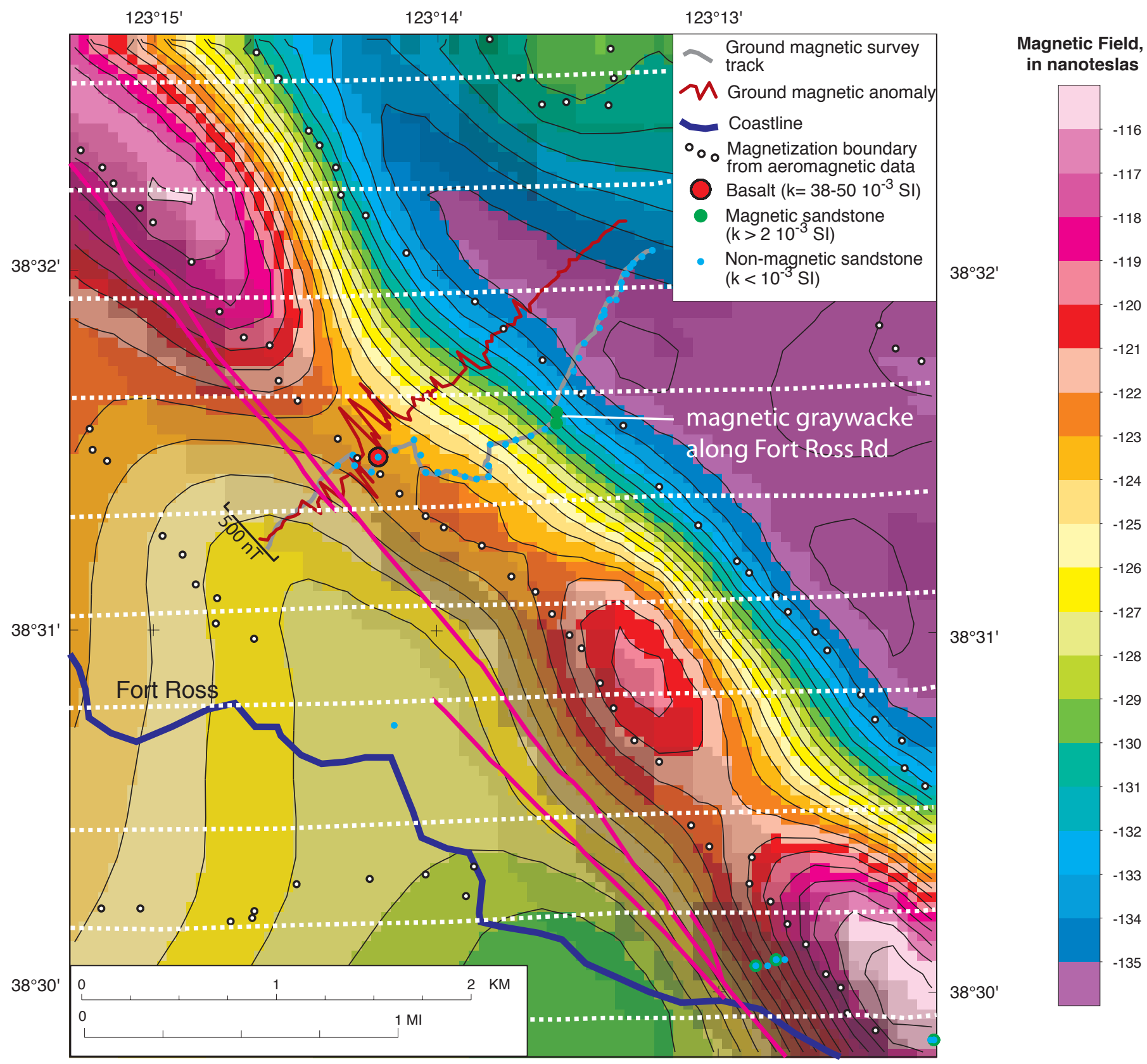

Figure 4. Aeromagnetic (color background), ground magnetic (brown line), and magnetic susceptibility data (red, green, and blue circles) for the Fort Ross transect. White dotted lines, flight lines. 


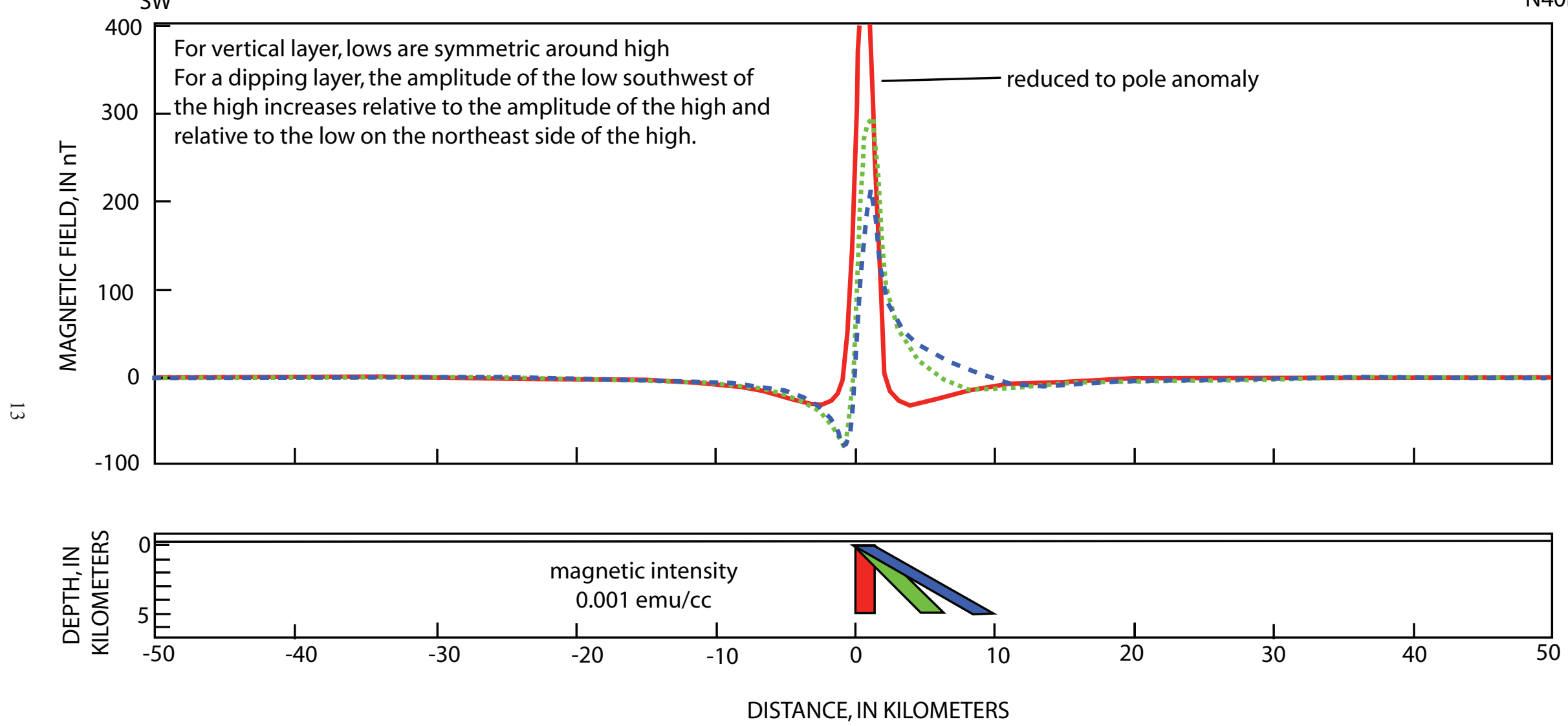

Figure 5. Predicted magnetic anomalies (reduced to pole) for vertical and dipping magnetic layers. For a vertical layer (shown in red), the lows are symmetric around the magnetic high. For layers that dip to the northeast (shown in green and blue), the amplitude of the low southwest of the high increases relative to the amplitude of the high and to the amplitude of the low on the northeast side of the high. 


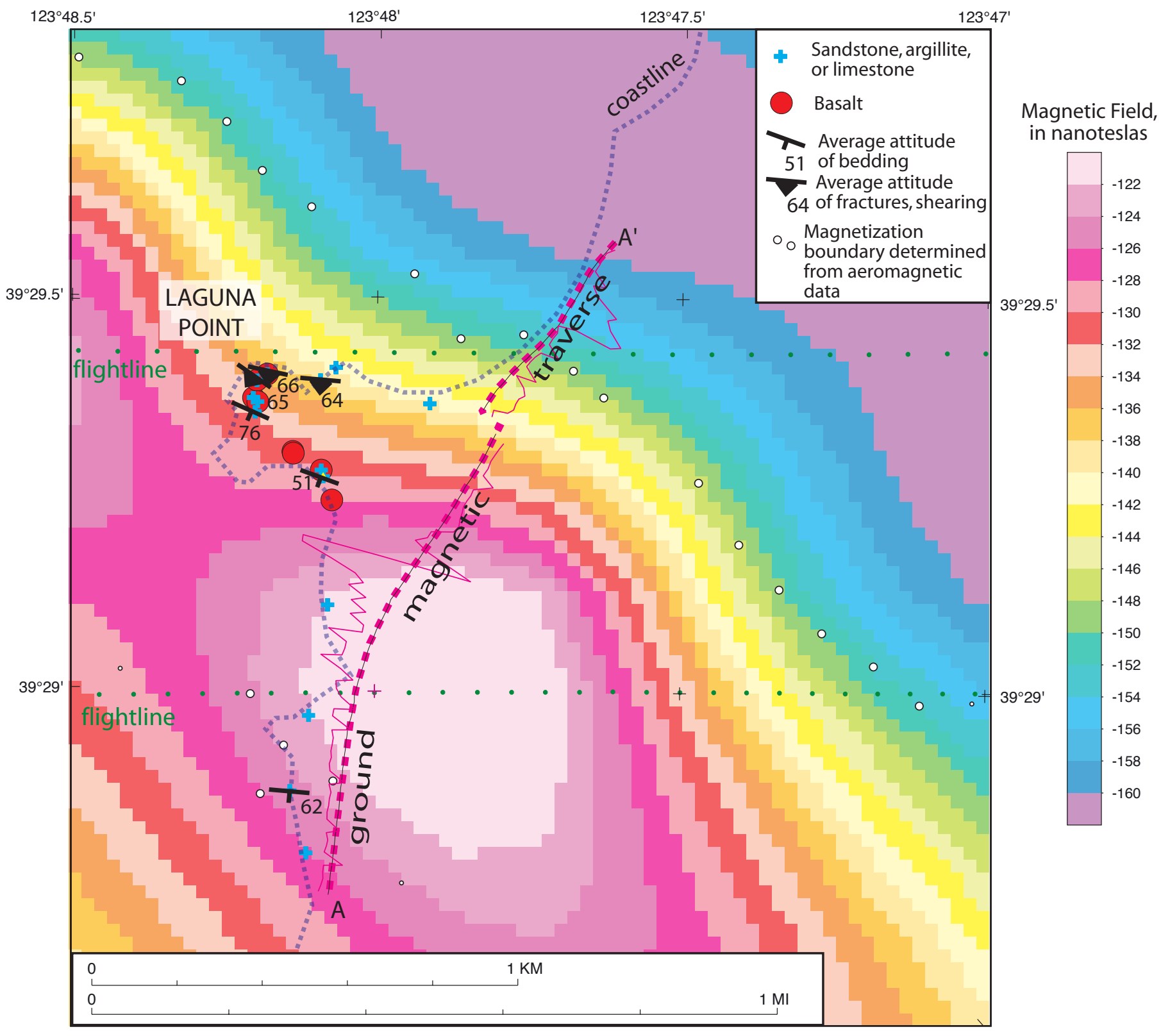

Figure 6. Aeromagnetic map of Laguna Point area, showing ground-magnetic traverse (heavy dotted magenta line), ground-magnetic data (thin magenta line), magnetization boundaries (white circles), and locations of magnetic susceptibility measurements. Flight lines marked by green dotted lines. 


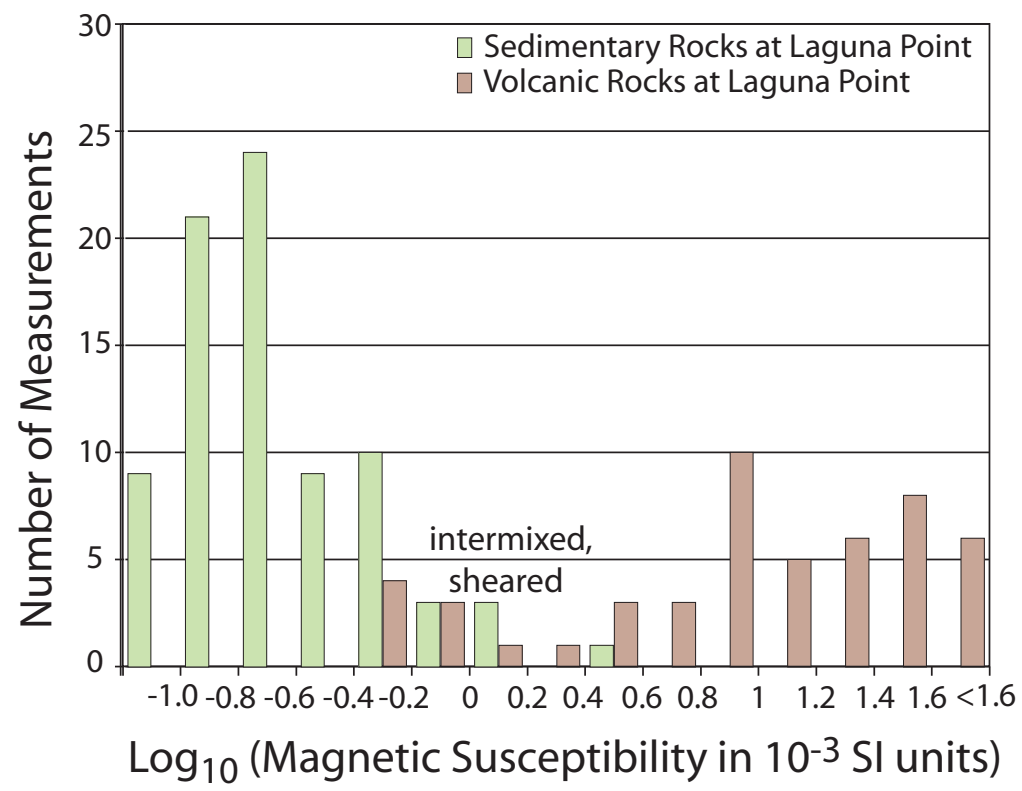

Figure 7. Magnetic susceptibility measurements from the Laguna Point area. 

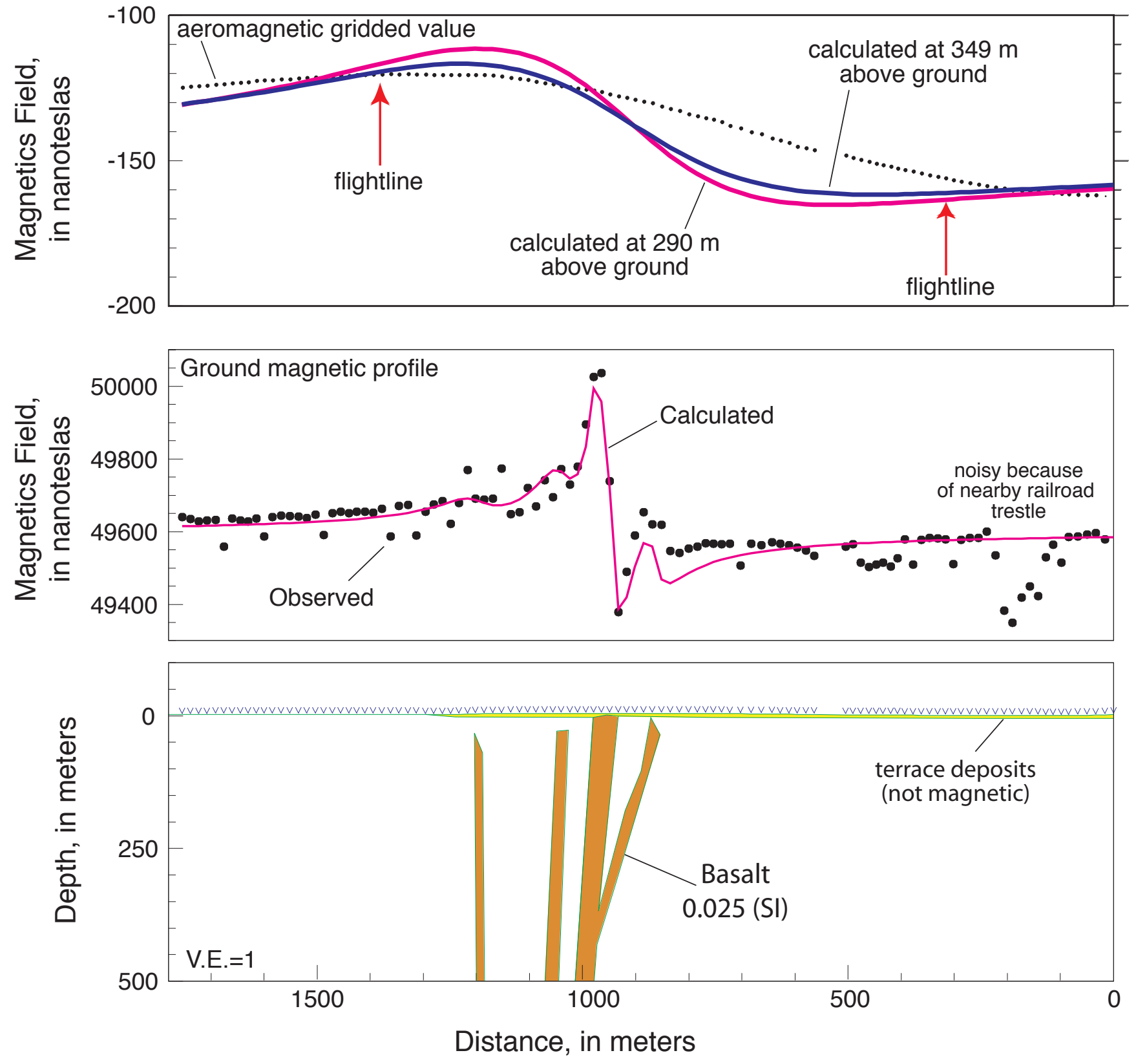

Figure 8. Model across the Laguna Point magnetic anomaly. 




Figure 9. Interpreted magnetic anomalies of the Coastal belt superposed on geology from figure 2 
Table 1. Aeromagnetic survey specifications.

[See area of survey on sheet 1, map A. GPS, Global Positioning System;; PNAV, Precision Navigation.; USGS, U.S. Geological Survey]

\begin{tabular}{|c|c|c|c|c|c|c|c|c|}
\hline Survey name & Archive \# & Date flown & $\begin{array}{l}\text { Flight-line } \\
\text { spacing }\end{array}$ & $\begin{array}{c}\text { Flight-line } \\
\text { direction }\end{array}$ & $\begin{array}{l}\text { Flight height above } \\
\text { average terrain }\end{array}$ & Position control & Sensor & Reference \\
\hline Clear Lake & 4168 & 02/95-07/95 & $450 \mathrm{~m}$ & EW & $300 \mathrm{~m}$ & GPS ? & Cesium Vapor & USGS (1996) \\
\hline Redding & 4134 & $01 / 85-02 / 85$ & $800 \mathrm{~m}$ & EW & $300 \mathrm{~m}$ & & Cesium & USGS (1985) \\
\hline $\begin{array}{l}\text { Santa Rosa/ } \\
\text { Napa Valley }\end{array}$ & 4188 & $12 / 2 / 96-1 / 12 / 97$ & $530 \mathrm{~m}$ & EW & $300 \mathrm{~m}$ & GPS/PNAV & Cesium Vapor & $\begin{array}{l}\text { USGS (1997); } \\
\text { USGS (2005) }\end{array}$ \\
\hline
\end{tabular}


Table 2. Interpreted strikes and dips from magnetic anomalies

[n/a, not applicable; nT; nanotesla; --, no data]

\begin{tabular}{|c|c|c|c|c|c|c|c|}
\hline $\begin{array}{l}\text { Map } \\
\text { Number } \\
\text { (on sheet 3) }\end{array}$ & $\begin{array}{l}\text { Anomaly } \\
\text { amplitude } \\
1=>20 \mathrm{nT} \\
2=10-20 \mathrm{nT} \\
3=<10 \mathrm{nT}\end{array}$ & $\begin{array}{l}\text { Dip confidence } \\
1=\text { best } \\
2=\text { intermediate } \\
3=\text { least }\end{array}$ & Strike & Dip direction & Dip angle & $\begin{array}{l}\text { Anomaly amplitudes } \\
\text { (south or west-side low } \\
\text { /central high/ } \\
\text { north or east-side low) }\end{array}$ & $\begin{array}{l}\text { Rock type (Bold } \\
\text { indicates rock type is } \\
\text { associated with outcrop; } \\
\text { italic indicates rock type } \\
\text { is inferred); comments }\end{array}$ \\
\hline 1a & 1 & 2 & NNW & $\mathrm{n} / \mathrm{a}$ & vertical & $-8 / 20 /-8$ & metavolcanic \\
\hline $1 b$ & 2 & 2 & NNW & $\mathrm{n} / \mathrm{a}$ & vertical & $-2 / 17 /-2$ & metavolcanic \\
\hline $2 b$ & 1 & 2 & EW & $\mathrm{n} / \mathrm{a}$ & vertical & $-10 / 26 /-10$ & metavolcanic \\
\hline $3 a$ & 1 & 2 & WNW & $\mathrm{n} / \mathrm{a}$ & vertical & $-8 / 34 /-8$ & metavolcanic \\
\hline $3 b$ & 3 & 3 & NNW & $\mathrm{n} / \mathrm{a}$ & vertical? & $-3 / 5 /-2$ & metavolcanic \\
\hline 4 & 1 & 2 & NNW & WSW & medium & $-10 / 45 /-16$ & $\begin{array}{c}\text { metavolcanic; } \\
\text { Griscom (1980) model is } \\
\text { WSW dip of } 35-40^{\circ}\end{array}$ \\
\hline $5 \mathrm{c}$ & 1 & 1 & NNW & ENE & steep & $-20 / 40 /-9$ & metavolcanic \\
\hline $5 \mathrm{~d}$ & 1 & 2 & NNW & ENE & medium & $-10 / 32 /-8$ & -- \\
\hline $6 \mathrm{a}$ & 2 & 2 & NNW & $\mathrm{n} / \mathrm{a}$ & vertical & $-4 / 12 /-4$ & -- \\
\hline $6 \mathrm{~b}$ & 3 & $2-3$ & NS & $\mathrm{E}$ & steep & $-2 / 4.4 /-1.7$ & -- \\
\hline 7 & 3 & 3 & NS & $\mathrm{E}$ & steep & $-4.95 / 4.6 /-4.85$ & -- \\
\hline 8 & 1 & 2 & NW & $\mathrm{NE}$ & steep & $-9 / 28 /-7$ & -- \\
\hline 9 & 2 & 3 & WNW & $\mathrm{n} / \mathrm{a}$ & vertical & $-2 / 12 /-2$ & -- \\
\hline 10 & 1 & 2 & WNW & NNE & steep & $-6 / 17 /-4$ & -- \\
\hline 11 & 1 & 1 & NS & $\mathrm{E}$ & shallow & $-19 / 40 /-10$ & metavolcanic \\
\hline 18 & 1 & 2 & WNW & ENE & shallow & $-12 / 23 /-2$ & metavolcanic \\
\hline 19 & 3 & 2 & NW & SW & shallow & $-0.5 / 4 /-1.5$ & metavolcanic \\
\hline $20 \mathrm{a}$ & 1 & 1 & NW & SW & steep & $-5 / 14 /-7$ & -- \\
\hline $20 b$ & 2 & 3 & NW & SW & shallow & $-3 / 7 /-5$ & -- \\
\hline 21 & 3 & 3 & NW & $\mathrm{NE}$ & steep & $-1.5 / 5.5 /-1$ & metavolcanic \\
\hline 22 & 1 & 1 & NW? & $\mathrm{NE}$ & medium & $-5 / 21 /-3$ & metavolcanic \\
\hline 23 & 2 & 2 & NS & $\mathrm{E}$ & steep & $-4.5 / 8.8 /-4.2$ & -- \\
\hline 24 & 1 & 1 & NW & $\mathrm{NE}$ & medium & $-6 / 18 /-3.5$ & -- \\
\hline $25 \mathrm{a}$ & 2 & 2 & NW & $\mathrm{n} / \mathrm{a}$ & vertical & $-5 / 6 /-5$ & -- \\
\hline $25 b$ & 2 & 2 & NW & SW & steep & $-2 / 16 /-3$ & metavolcanic \\
\hline 26 & 1 & 2 & NW & SW & shallow & $-6 / 25 /-11$ & graywacke \\
\hline 27 & 3 & 3 & NW & $\mathrm{NE}$ & medium & $-7 / 2 /-6$ & -- \\
\hline 28 & 1 & 2 & NW & $\mathrm{NE}$ & shallow & $-6 / 16 /-2$ & -- \\
\hline 29 & 2 & 2 & NW & $\mathrm{NE}$ & medium & $-6 / 10 /-4$ & -- \\
\hline 30 & 1 & 3 & NW & SW & medium & $-3 / 15 /-5$ & -- \\
\hline
\end{tabular}




\begin{tabular}{|c|c|c|c|c|c|c|c|}
\hline $\begin{array}{l}\text { Map } \\
\text { Number } \\
\text { (on sheet 3) }\end{array}$ & $\begin{array}{l}\begin{array}{l}\text { Anomaly } \\
\text { amplitude }\end{array} \\
1=>20 \mathrm{nT} \\
2=10-20 \mathrm{nT} \\
3=<10 \mathrm{nT}\end{array}$ & $\begin{array}{l}\text { Dip confidence } \\
1=\text { best } \\
2=\text { intermediate } \\
3=\text { least }\end{array}$ & Strike & Dip direction & Dip angle & $\begin{array}{l}\text { Anomaly amplitudes } \\
\text { (south or west-side low } \\
\text { /central high/ } \\
\text { north or east-side low) }\end{array}$ & $\begin{array}{l}\text { Rock type (Bold } \\
\text { indicates rock type is } \\
\text { associated with outcrop; } \\
\text { italic indicates rock type } \\
\text { is inferred); comments }\end{array}$ \\
\hline 31 & 2 & 3 & NW & $\mathrm{NE}$ & medium & $-7 / 9 /-5$ & -- \\
\hline 32 & 2 & 2 & NW & SW & shallow & $-6 / 13 /-13$ & -- \\
\hline $33 a$ & 2 & 2 & NW & $\mathrm{NE}$ & shallow & $-10 / 7 /-7$ & metavolcanic \\
\hline $33 b$ & 3 & 3 & NW & $\mathrm{NE}$ & shallow & $-3 / 2 /-1$ & $\begin{array}{c}\text { metavolcanic, } \\
\text { serpentinite }\end{array}$ \\
\hline 34 & 1 & 1 & NW & $\mathrm{NE}$ & shallow & $-17 / 45 / 0$ & -- \\
\hline 35 & 1 & 1 & NW & $\mathrm{NE}$ & shallow & $-12 / 16 /-7$ & -- \\
\hline 36 & 2 & 3 & NW & SW & steep & $-6 / 2 /-7$ & metavolcanic \\
\hline 37 & 2 & 3 & NS & $\mathrm{W}$ & steep & $-1.7 / 2.7 /-2.0$ & -- \\
\hline $38 \mathrm{a}$ & $1-2$ & 2 & NW & $\mathrm{n} / \mathrm{a}$ & vertical & $-3 / 10 /-3$ & metavolcanic \\
\hline $38 b$ & $1-2$ & 2 & NW & $\mathrm{NE}$ & steep & $-9 / 14 /-5$ & metavolcanic \\
\hline 39 & 2 & 3 & NW & $\mathrm{NE}$ & medium & $-3 / 7 /-2$ & -- \\
\hline 40 & 3 & 3 & NNW & SSW & steep & $-1.6 / 4 /-2.1$ & -- \\
\hline $41 \mathrm{a}$ & 1 & 2 & NW & $\mathrm{n} / \mathrm{a}$ & vertical & $-24 / 44 /-23$ & -- \\
\hline $41 \mathrm{~b}$ & 1 & 2 & NNW & $\mathrm{n} / \mathrm{a}$ & vertical & $-13 / 15 /-14$ & graywacke \\
\hline 42 & 2 & 2 & NW & $\mathrm{NE}$ & steep & $-6 / 8 /-5$ & -- \\
\hline 43 & 3 & 3 & NW & $\mathrm{NE}$ & medium & $-5 / 2 /-3$ & -- \\
\hline 44 & 3 & 3 & NW & $\mathrm{n} / \mathrm{a}$ & vertical & $-3 / 6 /-3$ & -- \\
\hline 45 & 1 & 1 & NW & $\mathrm{NE}$ & steep & $-6 / 29 /-5$ & metavolcanic \\
\hline 46 & 2 & 3 & WNW & $\mathrm{NE}$ & shallow & $-5 / 11 /-2$ & metavolcanic? \\
\hline 47 & 3 & 3 & NNW & ENE & medium & $-0.9 / 0.9 /-0.7$ & -- \\
\hline 48 & 3 & 3 & NW & $\mathrm{NE}$ & shallow & $-1.6 / 1.5 /-0.6$ & Coastal Belt Thrust \\
\hline 49 & 3 & 3 & NW & $\mathrm{NE}$ & shallow & $-1.8 / 1.2 /-1.0$ & Coastal Belt Thrust \\
\hline $50 \mathrm{a}$ & 3 & 3 & NNW & ENE & medium & $-2 / 3 /-1$ & Coastal Belt Thrust \\
\hline $50 \mathrm{~b}$ & 3 & 3 & NNW & $\mathrm{NE}$ & shallow & $-2 / 2 / 0$ & Coastal Belt Thrust \\
\hline 51 & 1 & 1 & NNW & ENE & steep & $-11 / 40 /-9$ & -- \\
\hline 52 & 2 & 2 & NNW & $\mathrm{n} / \mathrm{a}$ & vertical & $-2 / 8 /-2$ & metavolcanic \\
\hline 53 & 3 & 3 & NS & $\mathrm{n} / \mathrm{a}$ & vertical & $-1.4 / 2.3 /-1.3$ & Coastal Belt Thrust \\
\hline 54 & 2 & 2 & EW & $\mathrm{S}$ & shallow & $-1 / 9 /-5$ & metavolcanic \\
\hline 55 & 2 & 3 & NNW & ENE & steep & $-3 / 10 /-2$ & -- \\
\hline 56 & 3 & 3 & NNW & ENE & shallow & $-1.2 / 1.8 /-0.3$ & -- \\
\hline 57 & 3 & 2 & NW & $\mathrm{NE}$ & shallow & $-2.7 / 0.3 /-1.2$ & -- \\
\hline 58 & 1 & 3 & NW & $\mathrm{NE}$ & shallow & $-5 / 19 / 3$ & -- \\
\hline
\end{tabular}

